\title{
Profile of Farmers about Schemes for Doubling Farm Income
}

\author{
S. R. Gaikwad ${ }^{1 *}$, K. S. Thorat ${ }^{2}$, J. M. Deshmukh $^{3}$ and S. N. Gaykwad ${ }^{4}$ \\ ${ }^{1}$ College of Agriculture, Latur, India \\ ${ }^{2}$ Department of Extension Education, COA, Osmanabad, India \\ ${ }^{3}$ Department of Extension Education, COA, Latur, India \\ ${ }^{4}$ College of Agriculture, Latur, India \\ *Corresponding author
}

\section{A B S T R A C T}

The present study was conducted in Latur and Osmanabad district of Marathwada region of Maharashtra state in latur district out of ten tehsils two tehsils where selected randomly namely Latur and Chakur and in Osmanabad district out of eight tehsils two tehsils where selected randomly namely Osmanabad and Kalamb. For the purpose of study 2 villages

\section{Keywords}

Doubling Farm

Income, Age,

Education, Crop

Insurance

\section{Article Info}

Accepted:

04 November 2020

Available Online:

10 December 2020 from each selected tehsils, (Total 2 X $4=8$ ) were selected randomly for the selection of respondents. Thus total 8 villages were selected for study. From each selected village, 15 farmers were selected randomly. In this way, a total of 120 farmers (Total 8 X $15=120$ ) were considered as respondent for the present study. These selections were done by using simple random sampling method for the purpose of the study. The result of profile of farmers observed that majority $(66.66 \%)$ respondents belonged to middle age category, more than one third $(42.50 \%)$ of the respondents belonged to secondary education, majority $(65.83 \%)$ of the respondents were in engaged in farming only, majority (56.66 $\%$ ) of the respondents were possessing 1.01 to 2.00 ha of land and belonged to small farmers category while farming experience $(64.17 \%), 54.17$ percent of beneficiaries had high annual income ( above 1,49,175), while awareness about the crop insurance scheme $(59.17 \%)$ then 40.00 per cent had depend upon well as main source of irrigation,76.67 percent had medium social participation, 65.83 percent had medium used mass media exposure, while 72.50 percent belongs to medium extension contact category, 67.50 percent belong to medium risk orientation category and economic motivation $(70.83 \%)$.

\section{Introduction}

India is still an agrarian economy and a single bad monsoon takes toll on entire economy. Agriculture plays a vital role in India's economy. Over 58.00 per cent of the rural households depend on agriculture as their principal means of livelihood in India. Agriculture along with fisheries and forestry, contributes to more than 16.00 per cent of Gross Domestic Product (GDP) of country. However the growth in the agriculture sector in 2015-16 continued to be lower than the average of the last decade. Data suggests growth in farm income after 2011-12 has plummeted to more than one per cent, and has been reason for the sudden rise in agrarian distress in recent years. The 12th Five Year 
plan (2012-17) had targeted 04.00 per cent growth rate, however the rate of growth of Agricultural GDP has been around 02.00 per cent against the targeted 4 per cent. If by any measure agriculture has to grow at 04.00 per cent during the 12 Plan as projected, then agriculture growth must accelerate to 08.00 per cent, which means are going to miss on 12 plans by quite a long distance. Announcing the target of doubling farmer's income by 2022, the Hon'ble Finance Minister (FM) in his Union Budget Speech 2016-17, had highlighted the need to think beyond food security of the country and to focus on income security of the farmer.

To study the awareness of schemes for doubling farm income in Marathwada region this study is important. As compared to western Maharashtra, farmers in Marathwada region are laggards. Climatic condition is hot and less rainfall are the major causes. In this situation for doubling of farmers income Govt. are implementing many schemes. It is necessary to see whether farmers are giving response or not, and to study the major obstacles in receiving and implementing scheme.

\section{Materials and Methods}

The present study was carried out in the Latur and Osmanabad districts of Marathwada region of Maharashtra state. The latur district is situated on the Balaghat Plateau, about 540 meters to 638 meters from the mean sea level and Osmanabad district lies in the southern part of state. It lies on the Deccan plateau, about $600 \mathrm{~m}$ above sea level 540 meters to 638 meters from the mean sea level. The total area of Latur district is 7371 sq. $\mathrm{km}$ and the total area of Osmanabad district is 7569 sq. $\mathrm{km}$. the total population of latur district is 2,454,196 and total population of Osmanabad district is 1,657,576 (2011 census). In latur district, Manjara is the main river which flows on the Balaghat platueau along with its tributaries: Terna, Tawarja and Gharni and osmanabad district is Parts of the sina, Manjira and Terna River flow through the district.

The present investigation was carried out in two randomly selected districts out of the total 8 districts of Marathwada region namely Latur and Osmanabad district. In latur district out of ten tehsils two tehsils where selected randomly namely Latur and Chakur and in Osmanabad district out of eight tehsils two tehsils where selected randomly namely Osmanabad and Kalamb. For the purpose of study 2 villages from each selected tehsils, (Total 2 X $4=8$ ) were selected randomly for the selection of respondents. Thus total 8 villages were selected for study. From each selected village, 15 farmers were selected randomly. In this way, a total of 120 farmers (Total 8 X $15=120$ ) were considered as respondent for the present study. These selections were done by using simple random sampling method for the purpose of the study.

\section{Results and Discussion}

\section{Profile of the farmers}

The distributional analysis pertaining to age of the farmers indicated that, slight more than two third $(66.66 \%)$ of respondents belonged to middle age group. It was found that, more than one third $(42.50 \%)$ of the respondents were educated up to secondary school level. It was observed that majority $(65.83 \%)$ of respondents are engaged in agriculture as main occupation. It was found that, a majority $(56.66 \%)$ respondent belongs to small land holding category. It was found that, majority $(64.17 \%)$ of the beneficiaries had medium farming experience. It was observed that, more than half $(54.17 \%)$ of beneficiaries had high annual income (above 1,49,175). It was observed that majority $(59.17 \%)$ farmers have 
medium awareness about the crop insurance scheme. It was observed that, majority $(40.00 \%)$ of respondents depend upon well as main source of irrigation. It was observed that, slightly less than three fourth $(76.67 \%)$ of respondents had medium social participation. It was observed that, majority $(65.83 \%)$ of the respondents had medium used mass media exposure. It was found that; majority $(72.50 \%)$ of respondents belongs to medium extension contact category. It was found that, majority (67.50\%) of the respondents belong to medium risk orientation category. It was found that, majority $(70.83 \%)$ of the respondents belong to medium level of economic motivation category (Table 1).

Table.1 Profile of the farmers $n=120$

\begin{tabular}{|c|c|c|c|}
\hline Profile characteristics & Category & Frequency & Percentage \\
\hline \multirow[t]{3}{*}{ Age } & Young age (Up to 36 year) & 18 & 15 \\
\hline & Middle age (between 36 to 57 year) & 80 & 66.66 \\
\hline & Old age (Above 57 year) & 22 & 18.34 \\
\hline \multirow{5}{*}{ Education } & Illiterate & 2 & 1.67 \\
\hline & Primary education $\left(1^{\text {st }}\right.$ to $\left.4^{\text {th }}\right)$ & 13 & 10.83 \\
\hline & Secondary education $\left(5^{\text {th }}\right.$ to $\left.10^{\text {th }}\right)$ & 51 & 42.5 \\
\hline & Higher education $\left(11^{\text {th }}-12^{\text {th }}\right)$ & 29 & 24.17 \\
\hline & Graduation & 25 & 20.84 \\
\hline \multirow[t]{5}{*}{ Occupation } & Farming Labour & 01 & 0.84 \\
\hline & Farming & 79 & 65.83 \\
\hline & Farming + livestock & 20 & 16.67 \\
\hline & Farming + Service & 10 & 08.33 \\
\hline & Farming + Business & 10 & 08.33 \\
\hline \multirow[t]{5}{*}{ Land Holding } & Marginal (Up to 1 Ha.) & 12 & 10.00 \\
\hline & Small (1.01 to $2.00 \mathrm{Ha}$.) & 68 & 56.66 \\
\hline & Medium (2.01 to $4.00 \mathrm{Ha}$.) & 28 & 23.33 \\
\hline & Semi Medium (4.01 to $10.00 \mathrm{Ha}$.) & 12 & 10.00 \\
\hline & Big (10.00 Ha. Above) & 00 & 00.00 \\
\hline \multirow[t]{3}{*}{ Farming experience } & Low (Up to 15$)$ & 27 & 22.50 \\
\hline & Medium (between 15 to 40 ) & 77 & 64.17 \\
\hline & High (above 40) & 16 & 15.83 \\
\hline \multirow[t]{3}{*}{ Annual Income } & Low ( Up to 45,825 ) & 1 & 00.83 \\
\hline & Medium (between $45,825-1,49,175$ ) & 54 & 45.00 \\
\hline & High (Above 1,49,175) & 65 & 54.17 \\
\hline \multirow[t]{3}{*}{ Crop Insurance } & Low ( up to 2) & 27 & 22.50 \\
\hline & Medium (2-7) & 71 & 59.17 \\
\hline & High (Above 7) & 22 & 18.33 \\
\hline \multirow[t]{4}{*}{ Irrigation Facilities } & River & 0 & 00.00 \\
\hline & Pond & 5 & 4.17 \\
\hline & Well & 48 & 40.00 \\
\hline & Bore Well & 34 & 28.33 \\
\hline
\end{tabular}




\begin{tabular}{|c|c|c|c|}
\hline & Farm Pond & 12 & 10.00 \\
\hline & Dam & 0 & 00.00 \\
\hline & Canal & 2 & 1.67 \\
\hline & None of these & 19 & 15.83 \\
\hline \multirow[t]{3}{*}{ Social Participation } & Low (Up to 4) & 14 & 14 \\
\hline & Medium (between 4 to 9) & 92 & 92 \\
\hline & High (Above 9) & 14 & 14 \\
\hline \multirow[t]{3}{*}{ Mass media exposure } & Low (Up to 6) & 25 & 20.83 \\
\hline & Medium (6-12) & 79 & 65.83 \\
\hline & High ( Above 12) & 16 & 13.33 \\
\hline \multirow[t]{3}{*}{ Extension Contact } & Low (Up to 14$)$ & 20 & 16.67 \\
\hline & Medium (14 to 22$)$ & 87 & 72.50 \\
\hline & High (22 \& above) & 13 & 10.83 \\
\hline \multirow[t]{3}{*}{ Risk Orientation } & Low (Up to 20) & 29 & 24.17 \\
\hline & Medium (20 to 23 ) & 81 & 67.50 \\
\hline & High ( $23 \&$ above) & 10 & 08.33 \\
\hline \multirow[t]{3}{*}{ Economic motivation } & Low (Up to 21$)$ & 28 & 23.33 \\
\hline & Medium (between 21 to 24 ) & 85 & 70.83 \\
\hline & High (Above 24) & 07 & 05.84 \\
\hline
\end{tabular}

In conclusion the study indicated that, the profile of the farmers of schemes for Doubling Farm Income concluded from the present study that majorities of the respondents were having medium level of age, secondary school level of education, majority of the respondents had agriculture as a main occupation, small land holding category, medium farming experience and high annual income, medium awareness about crop insurance, well as a irrigation source, medium social participation, medium mass media exposure, medium extension contact, medium risk orientation, medium economic motivation.

\section{References}

Chand, R., Saxena, R. and Rana, S. 2015. Estimate and analysis of farm income in India, 1983-84 to 201112.Economics and Political Weekly.50 (22): 139-145.

Hinge, R. B., 2009. Diffusion and adoption of wine Grape production technology in
Maharashtra. M.Sc. (Agri.) Thesis, University of Agriculture Science, Dharwad, Karnataka (India).

https://vikaspedia.in/agriculture/policies-andschemes/policy-paper-on-doublingfarmers-income

Mohapatra, L., Dhaliwal, R.K. and Kaur, M. 2016 Farmers knowledge about the agricultural insurance scheme in Panjab. Indian Research Journal of Extension Education. 16(1): 49-53.

Nirban, A. J. 2004. Analysis of the Agricultural Produce Market Commitees in Konkan and Western Maharashtra with Reference to their Potential Role in Agricultural Marketing Extension. Ph.D. (Agri.) Thesis (Unpub.) MPKV, Rahuri

Wani S. P., Vijay Sandeep Jakkula and Dhirendra Singh (eds.) 2017. Doubling farmers' Income: KISAN-MITrA. Proceedings of National Workshop on Doubling Farmers' Income through Scalingup: (Knowledge-based KISAN-MITrA Integrated 
Sustainable Agriculture Network Mission India for Transforming Agriculture) Patancheru 502324.

Telangana, India. International Crops
Research Institute for the Semi-Arid Tropics.

\section{How to cite this article:}

Gaikwad, S. R., K. S. Thorat, J. M. Deshmukh and Gaykwad, S. N. 2020. Profile of Farmers about Schemes for Doubling Farm Income. Int.J.Curr.Microbiol.App.Sci. 9(12): 162-166. doi: https://doi.org/10.20546/ijcmas.2020.912.022 